JIPS, Vol. 2 No. 1

Halaman: 77 - 89

Mei 2021
Jurnal Inovasi Pembelajaran di Sekolah

DOI: https://doi.org/10.51874/jips.v1i01.8

ISSN 2774-9363 (Cetak)

ISSN 2774-9746 (Online)
JIPS

Jurnal Inovasi Pembelajaran di Sekolah

\title{
Peningkatan Kemampuan Guru dalam Pembelajaran Daring Menggunakan Model Classroom melalui Pengarahan Konsep Kepala Sekolah di SD Negeri Bugangan 01 Kota Semarang \\ Peni \\ SD Negeri Bugangan 01
}

\begin{abstract}
Abstrak
Latar belakang masalah penelitian ini untuk mengetahui bagaimana pelaksanaan pengarahan konsep pembelajaran daring oleh kepala sekolah untuk peningkatan kemampuan guru dalam menggunakan model classroom? dan bagaimana hasil peningkatan kemampuan guru SD Negeri Bugangan 01 dalam menggunakan model classroom setelah dilakukan pengarahan konsep pembelajaran daring oleh kepala sekolah?Metode penelitian yang digunakan yaitu metode penelitian tindakan sekolah (PTS) dan data yang digunakan adalah kemampuan guru dalam pembelajaran daring menggunakan media classroom melalui pemahaman konsep kepala sekolah di SD Negeri Bugangan 01 Kota Semarang. Populasi dalam penelitian ini yaitu semua guru SD Negeri SD Negeri Bugangan 01 Kota Semarang yang berjumlah 8 orang.Hasil penelitian ini kemampuan guru dalam pembelajaran daring menggunakan media classroom dari siklus I hasil penelitian dan observasi komponen tampilan media 64\%, tampilan bahan ajar 65\%, aksesibilitas $74 \%$, kejelasan petunjuk dan navigasi $75 \%$ dan nilai rata rata semua guru $70 \%$ masuk pada kriteri cukup sedangkan pada perbaikan siklus II, mengalami peningkatan dalam pembuatan administrasi daring terutama tampilan media $82 \%$, tampilan bahan ajar $81 \%$, aksesibilitas $82 \%$, kejelasan petunjuk dan navigasi $89 \%$ dengan nilai rata rata 84 identifikasi nilai baikPelaksanaan pengarahan konsep pembelajaran daring oleh kepala sekolah dapat meningkatkan kemampuan guru dalam pembelajaran daring menggunakan model classroom dan hasil pengarahan konsep kepala sekolah guru SD Negeri Bugangan 01menambah kepercayaan diri yang meningkat dan menghasilkan guru yang profesional terutama pada pembelajaran daring dan interaksi terhadap peserta didik.
\end{abstract}

Kata Kunci: Peran kepala sekolah, Media classroom

\section{Abstract}

The background of this research problem is to find out how the implementation of the direction of online learning concepts by the principal to increase the ability of teachers to use the classroom model? and how was the result of increasing the ability of SD Negeri Bugangan 01 teachers in using the classroom model after being briefed on the online learning concept by the principal? The research method used was the school action research method (PTS) and the data used was the teacher's ability in online learning using classroom media through understanding the concept of the principal in SD Negeri Bugangan 01 Semarang City. The population in this study were all 8 teachers of SD Negeri Bugangan 01 Semarang City. The results of this study were the teacher's ability in online learning using classroom media from the first cycle of research results and observations of $64 \%$ media display components, $65 \%$ display of teaching materials, $74 \%$ accessibility, $75 \%$ clarity of instructions and navigation and the average score of all teachers $70 \%$ entered into sufficient criteria while in the second cycle improvement, there was an increase in making online administration, especially $82 \%$ media display, $81 \%$ display of teaching materials, $82 \%$ accessibility, clarity of directions and navigation $89 \%$ with an average score of 84 identification of good values The implementation of online learning concept briefings by the principal can improve the ability of teachers in online learning using the classroom model and the results of the concept briefing of the principal of SD Negeri Bugangan 01 teachers increase self-confidence and produce teachers professionals especially in pem online learning and interaction with students.

Keywords: The role of the principal, Media classroom 


\section{PENDAHULUAN}

Proses pembelajaran sesungguhnya memiliki peran penting dalam upaya meningkatkan kemampuan pendidikan, sehingga pembelajaran yang diselenggarakan dengan mengedepankan kebermaknaan dan kemanfaatan bagi pembelajar. Hal tersebut diharapkan untuk menciptakan suasana pembelajaran yang dapat menstimulasi kemampuan peserta didik dalam mengeksplorasi dan menggali potensinya secara optimal dengan kreatif, inovatif, dan menyenangkan. Pembelajaran saat ini, lebih diarahkan pada aktivitas modernisasi dengan bantuan teknologi canggih dengan harapan dapat membantu peserta didik dalam mencerna materi pelajaran secara interaktif, produktif, efektif, inspiratif, konstruktif, dan menyenangkan. Selain itu, peserta didik juga diharapkan memiliki life skill dari aplikasi teknologi tersebut.

Menurut Miarso (2005:50) Perkembangan ilmu dan teknologi merupakan salah satu produk dari manusia yang terdidik, dan pada gilirannya manusia-manusia itu perlu lebih mendalami dan mampu mengambil manfaat dan bukan menjadi korban dari perkembangan ilmu dan teknologi sendiri. Mendalami serta mengambil manfaat dari perkembangan ilmu dan teknologi tidak mungkin dilakukan oleh semua manusia dengan kadar dan waktu yang sama. Keterbatasan manusia dan waktu menuntut adanya spesialisasi yang semakin menajam.

Program pembelajaran merupakan proses yang terpenting karena dari sinilah terjadi interaksi langsung antara pendidik dan peserta didik. Di sini pula campur tangan langsung antara pendidik dan peserta didik berlangsung sehingga dapat dipastikan bahwa hasil pendidikan sangat tergantung dari perilaku pendidik dan perilaku peserta didik. Dengan demikian dapat diyakini bahwa perubahan hanya akan terjadi jika terjadi perubahan perilaku pendidik dan peserta didik. Dengan demikian posisi pengajar dan peserta didik memiliki posisi strategis dalam meningkatkan kemampuan pembelajaran (Surakhmad, 2000: 31). Kemampuan pembelajaran yang dimaksudkan adalah tinggi rendahnya antusias peserta didik dalam pembelajaran dan efektif tidaknya proses belajar mengajar dalam mencapai tujuan pembelajaran yang didalamya tersirat hasil belajar peserta didik.

Salah satu masalah yang dihadapi dunia pendidikan saat ini adalah dampak pandemic COVID-19 yang kini mulai merambah ke dunia pendidikan, sehingga pemerintah berupaya untuk meliburkan seluruh lembaga pendidikan. selain itu pemerintah juga membatasi aktivitas orang di luar rumah upaya membatasi interaksi antar banyak orang hal itu bertujuan untuk memutus mata rantai penyebaran COVID-19. Kebijakan tersebut tidak hanya berlaku di negara Indonesia saja, tetapi juga di negara-negara yang telah terpapar COVID-19. Dengan adanya kebijakan tersebut maka sekolah menerapakan kegiatan belajar mengajar dari jarak jauh atau pembelajaran daring (dalam jaringan). Pelaksanaan proses pembelajaran jarak jauh era pandemic COVID-19 ini guru dituntut untuk memilih dan menggunakan 
metode yang tepat agar proses belajar mengajar tetap berlangsung dengan kata lain terciptalah interaksi edukatif.

Peran kepala sekolah dalam mengatasi masalah pembelajaran daring masa pandemik covid-19 memegang peranan yang sangat penting dalam mempengaruhi dan mengarahkan semua personil sekolah yang ada, agar dapat bekerja sama dalam usaha pencapaian tujuan organisasi sekolah. Tidak kalah pentingnya adalah produktivitas organisasi sekolah sebagaimana yang tampak dalam bentuk efektivitas dan efisiensi pengelolaannya serta kemampuan dan kuantitas dari lulusannya, banyak ditentukan oleh adanya suatu kedisiplinan kerja yang tinggi dalam penampilan kerja atau kinerja (work performance) dari para personil sekolah.

Kepala sekolah memiliki peran sebagai pemimpin di sekolahnya yang bertanggung jawab untuk memimpin proses pendidikan di sekolah pada masa pandemi covid-19, berkaitan dengan peningkatan mutu SDM, peningkatan profesionalusme guru, karyawan dan semua yang berhubungan dengan sekolah di bawah naungan kepemimpinan kepala sekolah. Dengan adanya era teknologi yang semakin berkembang ini maka progam pembelajaran diarahkan untuk bisa memanfaatkan teknologi dengan lebih baik. Salah satu pemanfaatan teknologi saat ini adalah eLearning menggunakan web untuk mengaksesnya. Tidak memungkiri karena banyak peserta didik sekarang memiliki smart phone jadi lebih mudah untuk mengaksesnya dari manapun berada dan kapanpun juga.

Pemanfaatan pembelajaran daring terutama media classroom yang akan dikembangkan di SD Negeri Bugangan 01dalam proses pembelajaran daring guru memberikan tugas kepada peserta didik dan mengirimkan hasil laporannya ke aplikasi google classroom. Selain itu juga peserta didik diberikan materi tambahan guna memahami lebih luas materi yang mungkin belum bisa tersampaikan langsung ketika tatap muka di kelas. Pembelajaran daring terutama melalui media classroom merupakan media alternatif untuk memberikan soal-soal ujian test dan imrpovisasi media yang tidak selalu menggunakan media cetak.

Kepala sekolah SD Negeri Bugangan 01 yang juga peneliti melalui observasi dan supervisi kelas terutama dalam penggunaan media classroom guru kurang maksimal dalam pelaksanaan pembelajaran daring. Guru masih beranggapan bahwa penggunaan media classroom sangat tidak efektip karena aplikasi yang digunakan terlalu banyak sehingga membingungkan dalam penggunaannya. Guru SD Negeri Bugangan 01dalam pembelajaran daring merupakan pengalaman pertama terutama dalam penggunaan media classroom sehingga merubah mainset guru masih berfokus pada pembelajaran tatap muka masih sangat sulit. Berdasarkan latar belakang di atas, peneliti akan mengkaji sejauh mana penerapan media classroom pada pembelajaran daring di SD Negeri Bugangan 01 apakah lebih efektip dan penelitian ini dapat dijadikan bahan evaluasi terhadap pengembangan media classroom yang ada di sekolahan. Dalam penetian ini diajukan judul "Peningkatan kemampuan guru melalui pengarahan 
konsep pembelajaran daring oleh kepala sekolah menggunakan model classroom di SD Negeri Bugangan 01 Kota Semarang.

\section{KAJIAN PUSTAKA}

\section{Tujuan dan Fungsi Kepemimpinan Kepala Sekolah}

Syarifuddin, (2002:56) tujuan Kepemimpinan merupakan kerangka ideal/filosofis yang dapat memberikan pedoman bagi setiap kegiatan pemimpin, sekaligus menjadi patokan yang harus dicapai. Tujuan dari kepemimpinan itu sendiri yaitu agar setiap kegiatan yang dilaksanakan dapat mencapai tujuan pendidikan pengajaran secara efektif dan efisien. Untuk mencapai tujuan seorang pemimpin, seorang pemimpin harus melakukan fungsi kepmimpinannya.

Supardi (2014:82) menyebutkan fungsi kepemimpinan sebagai berikut:

a. Menyusun kebijakan dan kebijaksanaan bersama

b. Mengikutsertakan anggota-anggota kelompok (guru-guru, tenaga kependidikan) dalam berbagai kegiatan.

c. Memberikan bantuan kepada anggota kelompok dalam menghadapi dan memecahkan persoalanpersoalan.

d. Membangkitkan dan memupuk semangat kelompok, atau memupuk moral yang tinggi kepada anggota kelompok.

e. Mengikut sertakan semua anggota dalam menetapkan putusan-putusan.

f. Membagi-bagi dan mendelegasikan kekuasaan dan tanggung jawab kepada semua anggota kelompok, sesuai dengan fungsi-fungsi dan kebijakan masing-masing.

g. Mempertinggi daya kreatif pada aggota kelompok.

h. Menghilangkan rasa malu dan rasa rendah diri pada anggota kelompok sehingga mereka berani mengmukakan pendapat demi kepentingan bersama.

Menurut Hadari Nawawi (1989:83), fungsi kepemimpinan pendidikan adalah:

a. Mengembangkan dan menyalurkan kebebasan berfikir dan mengeluarkan pendapat, baik secara perorangan maupun kelompok sebagai usaha mengumpulkan data/bahan dari anggota kelompok dalam menetapkan keputusan yang mampu memenuhi aspirasi didalam kelompoknya.

b. Mengembangkan suasana kerjasama yang efektif dengan memberikan penghargaan dan pengakuan terhadap kemampuan orang-orang yang dipimpin sehingga timbul kepercayaan pada dirinya dan kesediaan menghargai orang lain sesuai dengan kemampuan masing-masing.

c. Mengusahakan dan mendorong terjadinya pertemuan pendapat dengan sikap harga menghargai sehingga timbul perasaan ikut terlibat dalam kegiatan kelompok dan tumbuh perasaan tanggung jawab atas terwujudnya pekerjaan masing-masing sebagai bagian dari usaha pencapaian tujuan. 
d. Membantu menyelesaikan masalah-masalah, baik yang dihadapi secara perorangan maupun kelompok, dengan memberikan petunjuk_petunjuk dalam mengatasinya sehingga berkembang kesediaan untuk memecahkannya dengan kemampuan sendiri.

\section{Pentingnya Kepemimpinan Kepala Sekolah}

Kepemimpinan pendidikan berkaitan dengan masalah kepala sekolah dalam meningkatkan kesempatan untuk mengadakan pertemuan secara efektif dengan para guru dalam situasi yang kondusif. Dalam hal ini, perilaku kepala sekolah harus dapat mendorong kinerja para guru dengan menunjukkan rasa bersahabat, dekat, dan penuh pertimbangan terhadap para guru, baik secara individu maupun sebagai kelompok. Perilaku instrumental kepala sekolah merupakan tugas-tugas yang diorientasikan secara langsung diklarifikasi dalam peranan dan tugas-tugas para guru, sebagai individu dan sebagai kelompok. Perilaku kepala sekolah yang positif dapat mendorong, mengarahkan, dan memotivasi seluruh warga sekolah untuk bekerja sama dalam mewujudkan visi, misi, dan tujuan sekolah.

\section{Indikator Kepemimpinan kepala Sekolah efektif}

Kepala sekolah yang efektif sedikitnya harus mengetahui, menyadari, dan memahami tiga hal : (1) mengapa pendidikan yang berkualitas diperlukan disekolah; (2) apa yang harus dilakukan untuk meningkakan mutu dan produktivitas sekolah; (3) bagaimana mengelola sekolah secara efektif untuk mencapai prestasi yang tinggi. Kemampuan menjawab ketiga pertanyaan tersebut dapat dijadikan tolak ukur sebagai standar kelayakan apakah seseorang dapat menjadi kepala sekolah yang efefktif atau tidak.

\section{Pelaksanaan Pembelajaran Media Classroom}

Pengertian Pembelajaran

Kata pembelajaran berasal dari kata dasar "belajar" yang berarti suatu proses yang ditandai dengan perubahan pada diri seseorang. Perubahan sebagai hasil dari proses belajar dapat ditunjukkan dalam berbagai bentuk perubahan pengetahuan, pemahaman, sikap dan tingkah laku ketrampilan, kecakapan, kebiasaan, serta perubahan aspek-aspek lain yang ada pada diri individu yang sedang belajar (Sudjana, 2000: 28).

Pembelajaran menurut Thorndike terjadi melalui pembentukan asosiasi atau koneksi-koneksi antara pengalaman inderawi yakni persepsi terhadap stimulus atau peristiwa dan impuls-impuls saraf atau respon-respon yang memberikan manifestasinya dalam bentuk perilaku. Thorndike juga meyakini bahwa pembelajaran terjadi melalui rangkaian eksperimen trial and error atau menyeleksi dan mengoneksi (Nai, 2017: 102).

Pengertian-pengertian pembelajaran yang diutarakan para ahli mengutamakan kata kunci perubahan atau pengalaman. Dua kata kunci tersebut sangat dipengaruhi oleh arus pemikiran kaum Behavioral dalam 
memberi batasan tentang belajar dan pembelajaran yang merupakan dua sisi yang tak terpisahkan. Perubahan dan pengalaman dimaknai sebagai hakekat pembelajaran.

Batasan agak berbeda adalah yang dirumuskan dengan menggunakan kata kunci upaya yang mengindikasikan adanya pihak lain. Atau mekanisme lain yang harus ada seiring terjadinya proses belajar siswa. Mekanisme tersebut adalah guru, media, serta berbagai sumber, baik cetak maupun elektronik yang kemudian menjadi prasyarat belajar dan pembelajaran, sehingga batasan pembelajaran menjadi lebih sistematis jika dibahas melalui istilah teknologi pembelajaran (Nai, 2017: 122).

Berdasarkan definisi diatas penulis menyimpulkan bahwa pembelajaran merupakan suatu kegiatan yang memungkinkan didalamnya terdapat interaksi antara pendidik dan peserta didik sehingga terjadi aktivitas belajar.

\section{Fitur Google Classroom}

Adapun fitur yang terdapat dalam google classroom sebagai berikut:

1) Assignments (Tugas)

Penugasan disimpan dan dinilai pada rangkaian aplikasi produktivitas google yang memungkinkan kolaborasi antara guru dan siswa. Atau siswa kepada siswa.

\section{2) Grading (Pengukuran)}

Google classroom mendukung banyak skema penilain yang berbeda. Guru memiliki pilihan untuk melampirkan file ke tugas dimana siswa dapat melihat, mengedit, atau mendapatkan salinan individual. Siswa dapat membuat file dan kemudian menempelkannya ke tugas jika salinan file tidak dibuat oleh guru.

Guru memiliki pilihan untuk memantau kemajuan setiap siswa pada tugas dan dimana mereka dapat memberi komentar dan edit. Berbalik tugas dapat dinilai oleh guru dan dikembalikan dengan komentar agar siswa dapat merevisi tugas dan masuk kembali. Setelah dinilai, tugas hanya dapat diedit oleh guru jika guru mengembalikan tugas masuk.

3) Communication (Komunikasi)

Pengumuman dapat diposkan oleh guru ke arus kelas yang dapat dikomentari oleh siswa sehingga terjadi komunikasi dua arah antara guru dan siswa. Beberapa jenis media dari produk google seperti file video YouTube dan google drive dapat dilampirkan ke pengumuman dan pos untuk berbagai konten.

\section{4) Time-Cost (Hemat Waktu)}

Guru dapat menambahkan siswa dengan memberi kode untuk mengikuti kelas. Guru juga mengelola kelas dapat menggunakan kembali pengumuman, tugas, atau pertanyaan yang ada dari kelas lain. Juga dapat berbagi tulisan di beberapa kelas dan kelas arsip untuk kelas masa depan. Pekerjaan siswa, 
tugas, pertanyaan, nilai, komentar semua dapat diatur oleh satu atau semua kelas, atau diurutkan menurut apa yang dikaji.

5) Archieve Course (Arsip Program)

Arsip juga untuk membangun juga mempertahankan kelas mereka saat ini. ketika kursus diarsipkan, guru dan siswa dapat melihatnya namun tidak dapat melakukan perubahan apapun sampai dipulihkan.

6) Mobile Aplication (Aplikasi dalam Telepon Genggam)

Aplikasi memberikan pengguna mengambil foto dan menempelkannya ke tugas mereka, berbagai file dari aplikasi lain dan mendukung akses online.

7) Privacy (Privasi)

Berbeda dengan layanan konsumen google, google classroom, sebagai bagian dari G Suite for Education, tidak menampilkan iklan apapun dalam antarmuka untuk siswa, fakultas, dan guru dan data penggunaan tidak dipindai atau digunakan untuk tujuan periklanan. Semua fitur tersebut dapat digunakan oleh guru selama pembelajaran. Pada dasarnya tahap awal yang dilakukan yakni dengan melakukan login dengan menggunakan akun G suit for Education atau google pribadi/email google (Iskandar dkk, 2020: 145-146) .

\section{Cara Penggunaan Google Classroom}

Dalam memulai menggunakan google classroom kita terlebih dahulu masuk ke akun google dan kemudian mencari produk google tersebut, setelah masuk pada akun google classroom kita dihadapakan pada tiga menu utama yaitu, stream (aliran), classwork (aktivitas siswa), dan people (orang). Stream adalah fasilitas google class untuk membuat pengumuman, mendiskusikan gagasan, atau melihat aliran tugas, materi, quiz dari topik-topik yang diajarkan guru.

Classwork dapat digunakan guru untuk membuat soal tes, pretes, quiz, mengunggah materi, dan mengadakan refleksi. Pada menu people guru dapat mengundang siswa dengan kode akses yang telah tersedia pada bilah people, sedangkan untuk mengundang guru lain sebagai kolaborator cukup dengan mengundang guru melalui email masing-masing. Materi yang diunggah pada bilah classwork dapat berupa file word, exel, powerpoint, pdf maupun video. Hal ini dilakukan guru untuk mengakomodasi adanya perbedaan terhadap kecapatan berpikir, latar belakang pengetahuan awal, dan perbedaan pada learning style peserta didik (Millatana dalam Iskandar dkk, 2020: 143).

\section{Kemampuan Guru dalam Pembelajaran Daring}

Kesiapan Guru juga menjadi faktor penting dalam mengukur kesiapan guru, karena guru juga berkaitan langsung dengan peserta didik dalam proses pembelajaran. N. Hadi and Nur (2013) menyatakan bahwa sumber daya manusia dalam hal penerapan E-learning disekolah terdiri dari guru dan siswa. Guru memegang peran penting dalam sukses tidaknya pendidikan anak (Baharrudin, 2014: 126). Diperkuat 
dengan pendapat lain bahwa guru memiliki peran penting dalam mentransfer pengetahuan kepada peserta didik melalui E-learning (Saekow and Samson: 2011). Hadi (2008, 22) juga mengemukkan bahwa tugas dari pendidik adalah perantara atau penghubung aktif yang menjebatani antara anak didik dengan tujuan pendidikan yang telah dirumuskan.

Guru merupakan satu komponen manusiawi dalam proses belajar mengajar yang ikut berperan dalam usaha pembentukan sumber daya manusia yang potensial di bidang pembangunan (Sardiman, 2007: 125). Nurfuadi (2012 :108) juga berpendapat tentang guru bahwa guru merupakan semua orang yang berwenang dan bertanggung jawab terhadap pendidikan peserta didiknya baik secara individual maupun klasikal, baik di sekolah maupun diluar sekolah yang memegang tugas berat sehingga untuk dapat menjadi guru diajukan syaratsyarat pokok tertentu. Mulyasa (2006) mengemukakan peran guru dalam pembelajaran berperan sangat banyak yaitu (1) sebagai pendidik (2) sebagai pengajar (3) sebagai pembimbing (4) sebagai pelatih (5) sebagai penasehat (6) sebagai pembaharu (7) sebagai model dan teladan (8) sebagai pribadi (9) sebagai peneliti (10) sebagai pendorong kreatifitas (11) sebagai pembangkit pandangan (12) sebagai pekerja rutin (13) sebagai pemindah kemah (14) sebagai pembawa cerita (15) sebagai aktor (16) sebagai emansipator (17) sebagai evaluator (18) sebagai pengawet (19) sebagai kulminator.

Kesiapan guru menurut persepsi guru terdapat lima indikator yaitu (1) saya mengetahui apa itu Elearning (2) saya merasa E-learning sangat meningkatkan hasil mengajar dan belajar (3) saya merasa saat ini saat yang tepat untuk menggunakan E-learning di sekolah saya (4) saya siap menggabungkan Elearning dalam pembelajaran saya (5) saya mempunyai kemampuan IT untuk menyiapkan materi pada Elearning (Teddy \& Swatman, 2006). Indikator kemampuan IT dijabarkan menjadi kemampuan komputer dan internet agar lebih rinci, kemudian ditambahkan dengan aspek kemampuan guru dalam belajar menggunakan E-learning meliputi menjalankan perintah dilayar dan penggunaan teknologi sehari-hari, serta ditambahkan pula penilaian kerjasama antar guru dan peserta didik dalam penggunaan E-learning. Dengan mempertimbangkan kesiapan guru dalam penerapan E-learning diharapkan kelebihan atau manfaat E-learning bagi guru dapat diimplementasikan dengan baik. Penjabaran setiap aspek sebagai berikut.

Guru perlu memiliki pengetahuan yang cukup luas (Suparlan, 2005: 113). Sagala (2011: 31) menyatakan kompetensi dasar yang harus dimiliki seorang guru dikembangkan melalui kurikulum Lembaga Pendidikan Tenaga Kependidikan (LPTK). Sepuluh kompetensi tersebut adalah (1) kemampuan menguasai bahan pelajaran yang disajikan (2) kemampuan mengelola program belajar mengajar (3) kemampuan mengelola kelas (4) kemampuan menggunakan media atau sumber belajar (5) kemampuan mengasai landasanlandasan kependidikan (6) kemampuan mengelola interaksi belajar mengajar (7) kemampuan menilai peserta didik (8) kemampuan mengenal fungsi dan program (9) kemampuan 
mengenal dan menyelenggarakan administrasi sekolah (10) kemampuan memahami prinsip-prinsip dan menafsirkan hasil penelitian pendidikan. Dalam konteks pembicaraan guru yang efektif, Kathleen Hodeman sangat yakin akan pentingnya pengetahuan (McEwan, 2014: 120) Guru lebih baik berpengetahuan luas mengetahui tentang segala sesuatu yang penting-penting yang berkaitan dengan tugasnya (Purwanto, 2009: 148). Pengetahuan guru sangat dibutuhkan untuk dapat menuntun peserta didiknya untuk mencapai tujuan pembelajaran. Guru yang dangkal penguasaan ilmunya, akan mengalami kesulitan dalam berinteraksi dengan peserta didiknya, untuk masa kini dan masa yang akan datang (Nurfuadi, 2012: 109). Diharapkan guru mengetahui manfaat dan kelebihan E-learning sehingga terpacu untuk menggunakannya.

\section{METODE PENELITIAN}

Metode yang digunakan dalam penelitian ini adalah penelitian tindakan sekolah. Penelitian menunjukkan pada suatu kegiatan mencermati suatu obyek dengan cara menggunakan cara dan aturan metodologi tertentu untuk memperoleh data atau informasi yang bermanfaat dalam meningkatkan mutu suatu hal yang menarik minat dan penting bagi peneliti. Tindakan : menujukkan pada suatu obyek kegiatan yang sengaja dilakukan dengan tujuan tertentu. Dalam penelitian berbentuk rangkaian siklus kegiatan untuk siswa. Sekolah : dalam hal ini tidk terikat pada pengertian ruang kelas, tetapi dalam pengertian yang lebih spsifik, yakni sekelompok siswa yang dalam waktu yang sama, menerima pelajaran yang sama dari guru yang sama pula.

\section{Subjek dan Objek Penelitian}

Kegiatan yang menjadi setting Penelitian Tindakan Sekolah adalah pembelajaran daring dengan menggunakan model classroom menghadapi pandemi covid-19. Penelitian dilakukan terhadap 6 Guru kelas, 1 guru PJOK dan 1 guru PAI.

\section{Instrumen tes}

Instrumen tes digunakan untuk mengungkapkan data tentang kemampuan guru melalui pembelajaran daring dengan menggunakan model classroom. Untuk mengetahui tingkat kemampuan pembelajaran daring dengan menggunakan model classroom digunakan alat ukur berupa tes performansi penggunaan model classroom. Tes ini menggunakan pembelajaran daring dengan menggunakan model classroom sehingga sesuai dengan tingkat perkembangan guru untuk berani tampil dalam menyampaikan hasil pembelajaran. Penilaian hasil dalam kompetensi dasar pengunaan pembelajaran daring dengan menggunakan model classroom yang sesuai dengan indikator pembelajaran yang harus dicapai guru, yaitu (1) mampu penggunaan model classroom dan ketrampilan penggunaan model classroom yang baik, 
dan (2) mampu dalam mengoperasikan pembelajaran daring dengan menggunakan model classroom dengan baik.

\section{HASIL DAN PEMBAHASAN}

\section{Hasil}

\section{Siklus I}

Berdasarkan hasil pengamatan dan respon pada siklus I diketahui bahwa hasil yang diperoleh belum memenuhi keinginan peneliti dalam penerapan Model classroom dalam pembelajaran maka pada refleksi peneli dan teman sejawat menganalisa kekurangan dan kelemahan guru terutama:

1) Bahan ajar guru harus lebih kreatif lagi terutama dalam kata perintah

2) Media pembelajaran yang dibuat terutama video durasi waktu untuk diperpendek tapi tidak mengurangi isi materi.

3) Guru harus mengetahui kesulitan peserta didik dalam memnbuka dan mengirim tugas melalui classroom.

4) Diskusi dan kerjasama antar guru diperkuat lagi, agar permasalahan segera teratasi.

Melihat hasil kinerja pada siklus I yang kurang memenuhi maka diperlukan perbaikan pada tindakan siklus II. Kelemahan dan kekurangan yang terjadi selama siklus I maka akan dicarikan solusi dan akan dilakukan perbaikan-perbaikan dalam melakukan siklus II.

\section{Siklus II}

Kegiatan observasi yang dilakukan peneliti pada siklus II dengan diskusi bersama dewan guru dan teman sejawat antara lain:

1) Guru pada siklus II ini sudah memahami kemampuan dalam penggunaan model classroom pada pembelajaran daring, baik dalam diskusi dengan teman maupun interaksi pembelajaran daring terhadap peserta didik.

2) Guru sudah paham dengan aplikasi classroom sehinnga dalam pemaparan hasil kerja kemampuan pembelajaran daring sudah tampak kepercayaan dirinya bertambah.

3) Hasil Penelitian kemampuan guru dalam pelaksanaan pembelajaran daring dengan menggunakan model classroom sudah tampak keberanian dan percaya diri yang tinggi dalam memberikan materi kepada peserta didik.

4) Penelitian ini sudah berjalan dengan baik sesuai dengan harapan peneliti dimana kemampuan guru dalam pembelajaran daring terutama dengan peserta didik sudah berjalan sesuai rencana yang diharapkan.

5) Melihat hasil dari penelitian ini yang sudah sesuai dengan harapan tetapi kemampuan guru dalam pembelajaran daring tetap harus ditingkatkan lagi terutama memberikan materi yang bervariasi. 
6) Hasil penelitian ini sebagai acuan guru dalam pembelajaran daring dapat menambah profesional guru dalam meghadapi masa pandemi covid-19.

\section{Pembahasan Hasil Penelitian}

Kemampuan guru dalam penggunaan model Classroom pada pembelajaran daring pada observasi pra siklus masih dengan hasil kurang, sedangakan pada siklus I ada kenaikan perbaikan beberapa guru. Sedangkan pada hasil siklus II dapat dilihat pada tabel 4.3 dimana kemampuan guru dalam penggunaan model classroom sudah seesuai dengan harapan peneliti. Kemampuan guru ini sudah sesuai dengan kisi kisi observasi dan kisi kisi penilaian pembelajaran daring dengan menggunakan model classroom pada masa pandemi covid-19. Kemampuan guru dalam penggunaan model classroom ini paham dengan aplikasi dan kemampuan dalam pembelajaran interaksi daring dengan peserta didik.

Tabel: Perbandingan Rata-Rata Indikator Siklus I Dan Siklus II

\begin{tabular}{|l|c|c|}
\hline Item & Siklus I & Siklus II \\
\hline Tampilan Media & 64 & 82 \\
\hline Tampilan Bahan Ajar & 65 & 81 \\
\hline Aksesibilitas & 74 & 82 \\
\hline $\begin{array}{l}\text { Kejelasan petunjuk dan } \\
\text { navigasi }\end{array}$ & 75 & 89 \\
\hline Rata Rata & 70 & 84 \\
\hline
\end{tabular}

\section{DAFTAR PUSTAKA}

Syarifuddin, 2002 Manajemen Mutu Terpadu dalam Pendidikan, Konsep, Strategi, dan Aplikasi, Jakarta: Grafindo.

Supardi,2014 Kinerja Guru, Jakarta: PT Raja Grafindo Persada Rosdakarya,2014.

Hadari Nawawi, 1989. Adminisrasi Pendidikan, Jakarta: Haji Masagung.

E. Mulyasa, 2013.Manajemen dan Kepemimpinan Kepala Sekolah, Jakarta: PT. Bumi Aksara

Luk-luk Nur Mufidah,2009. Supervisi Pendidikan, Yogyakarta: Teras

Lantip Diat Prasojo dan Sudiyono, 2011.Supervisi Pendidikan, cet. I, Yogyakarta: Gava Media.

Made Pidarta, 2009. Supervisi Pendidikan Kontekstual, Jakarta: Rineka Cipta.

Jasmani Asf dan Syaful Mustofa, 2013Supervisi Pendidikan Terobosan Baru dalam Peningkatan Kinerja Pengawas Sekolah dan Guru,cet. I, Jogjakarta: Ar-Ruzz Media.

Sudjana, Nana. 2000. Dasar-dasar Proses Belajar Mengajar. Bandung: Sinar Baru Algensindo. 2010. Dasar-Dasar Proses Belajar Mengajar. Bandung: Sinar Baru Algensindo

Sudjana, Nana \& Ahmad Rivai. 2001. Media Pengajaran. Bandung: Sinar Baru Algesindo 
Nai, Firmina Angela. 2017. Teori Belajar dan Pembelajaran Implementasi dalam Pembelajaran Bahasa Indonesia. Yogyakarta: Deepublish. https://books.google.co.id/books?id=yJsnDwAAQBAJ\&printsec=frontcover\&dq=teori+belajar+d an+pembelajaran\&hl=en\&sa=X\&ved=0ahUKEwjbvPiFuJnpAh UaAXlKHXqQCb4Q5AElNjAC (Diakses pada tanggal 20 April 2020, Pukul 13.15 WIB).

Djamarah, Syariful Bahri \& Aswan Zain. 2006. Strategi Belajar Mengajar: Rineka Cipta.

Iskandar, dkk. 2020. Aplikasi Pembelajaran TIK. Yayasan Kita Menulis.https://books.google.co.id/books?id=_LfQDwAAQBAJ\&pg=PA68\&dq=aplikasi+pembe lajaran+tik\&hl=en\&sa=X\&ved=0ahUKEwilt66ZuZnpAhWUfH0KHfGcClEQ6AElKTAA\#v=on epage \&q=aplikasi\%20pembelajaran\%20tik\&f=f alse (diakses pada tanggal 20 April 2020, pukul 14.00 WIB).

Japar, dkk. 2019. Media dan Teknologi Pembelajaran PPKn. https://books.google.co.id/books?id=vHzYDwAAQBAJ\&pg=PA165\&dq=media+pembelajaran+ pkn\&hl=en\&sa=X\&ved=0ahUKEwjgpuLygqLpAhVKSX0KHQHSBsYQ6AEIKTAA\#v=onepag e\&q=media\%20pembelajaran\%20pkn\&f=false (diakses pada tanggal 21 April 2020, pukul 09.00 WIB).

Ibadurrahman, Muhammad Alief. 2020. Coronavirus Asal Usul, Penyebaran, Dampak, dan Metode Pencegahan Efektif Pandemi Covid-19. https://books.google.co.id/books?id=dRXbDwAAQBAJ\&hl=id. (diakses pada tanggal 20 April 2020, pukul 13.25 WIB).

Medico, Bruno Del. 2020. Coronavirus Covid-19, Membelah Diri, Cara Menghindari Penularan, Bagaimana Melindungi Keluarga dan Pekerjaan Anda: Manual Pertama untuk Mempertahankan Diri Terhadap Infeksi CoronaVirus. https://books.google.co.id/books?id=FCfUDwAAQBAJ\&hl =id (diakses pada tanngal 21 April 2020, pukul $08.00 \mathrm{WIB}$ ).

Baharrudin. (2014). Pendidikan dan Psikologi Perkembangan. Yogyakarta: ArRuzz Media.

Hadi, A. S. (2008). Pendidikan Suatu Pengantar. Surakarta: UNS Press.

Hadi, N., \& Nur, I. (2013). Tingkat Kesiapan (Readiness) Implementasi E-learning di Sekolah Menengah Atas Kota Yogyakarta. Yogyakarta.

Sardiman. (2007). Interaksi dan Motivasi Belajar Mengajar. Jakarta: Rajagrafindo Persada.

Nurfuadi. (2012). Profesionalisme Guru. Purwokerto: STAIN Press.

Mulyasa, E. (2003). Managemen berbasis sekolah Konsep Strategis, dan implementasi. Bandung: Remaja Rosdakarya.

Mulyasa, E. (2006). Kurikulum Berbasis Kompetensi Konsep, Karakteristik, dan Implementasi. Bandung: Remaja Rosdakarya.

Teddy, \& Swatman, P. M. C. (2006). E-learning Readiness of Hong Kong Teachers. The Journal of Education Research University of South Australia.

Suparlan. (2005). Menjadi Guru Efektif. Yogyakarta: HIKAYAT Publising. 
Suparlan, M. A. (2014). Desain Instruksional Modern: Panduan Para Pengajar dan Inovasi Pendidikan. Jakarta: Erlangga.

Sagala, S. (2011). Kemampuan Profesional Guru dan Tenaga Kependidikan. Bandung: Alfabeta.

McEwan, E. K. (2014). 10 Karakter yang Harus Dimiliki Guru yang Sangat Efektif. Jakarta: Indeks.

Purwanto, N. (2009). Ilmu Pendidikan Teoritis dan Praktis. Bandung: Remaja Rosdakarya.

Sutopo, A. H. (2012). Teknologi Informasi dan Komunikasi dalam Pendidikan. Yogyakarta: Graha Ilmu.

Sardiman. (2007). Interaksi dan Motivasi Belajar Mengajar. Jakarta: Rajagrafindo Persada.

Arif Rohman. (2012). Kebijakan Pendidikan: Analisis Dinamika Formulasi dan Implementasi. Yogyakarta: Aswaja Pressindo.

. (2013). Guru dalam Pusaran Kekuasaan: Potret Konspirasi dan Politisasi. Yogyakarta: Aswaja Pressindo.

Onisimus Amtu. (2011). Manajemen Pendidikan di era Otonomi Daerah: Konsep, Strategi, dan Implementasi. Bandung: Alfabeta.

Depdikbud. (2003). Undang-Undang Republik Indonesia Nomor 20 Tahun 2003 tentang Sistem Pendidikan Nasional.

Depdikbud. (2005). Undang-Undang Republik Indonesia Nomor 14 Tahun 2005 tentang Guru dan Dosen.

Udin Syaefudin Sa’ud. (2011). Pengembangan Profesi Guru. Bandung: Alfabeta.

E. Mulyasa. (2013). Uji Kompetensi dan Penilaian Kinerja Guru. Bandung: Remaja Rosdakarya.

Martinis Yamin dan Maisah. (2010). Standarisasi Kinerja Guru. Jakarta: Gaung Persada Press. 